\title{
Role of Foundation in the Implementation of Madrasah (Case of Baitul Muttaqiin Foundation in Songgom Brebes)
}

\author{
Iyoh mastiyah ${ }^{1}$ and Farida Hanun ${ }^{2}$ \\ \{mastiyah9@gmail.com ${ }^{1}$, farida_ridwan@yahoo.com² ${ }^{2}$, \\ Research \& Development and Training Agency, MoRA $+622131924509^{1}$
}

\begin{abstract}
This research reveals the role of the Baitul Muttaqiin Foundation in the implementation of madrassas in Brebes Regency. The research problem is focused on the role of the Foundation in meeting eight education standards. The study uses qualitative methods with data collection techniques interview, observation, and documentation. Research findings indicate that the Foundation has made efforts in meeting educational standards, but is still limited. The Foundation's efforts are more dominant in fulfilling infrastructure facilities and accepting new students and the learning process. While other aspects are less attention. In particular, handling conflicts have no solution. Likewise, managerial guidance and network expansion have not been sufficient. Seen in the supervision, monitoring, and guidance of both the management of madrasas and human resource improvement is not optimal. Therefore, madrasa development does not show progress, even tends to decline both in terms of public interest and the quality of madrasa output
\end{abstract}

Keywords: Role, Foundation, Organizing, Madrasah

\section{Introduction}

The number of Madrasah Aliyah education units in Brebes Regency is 27 institutions. Of these 23 MA are private entities managed by the Foundation. At present, MA Education institutions are managed by the Foundation, especially MA Daarul Istiqomah, which are still low in output. This was alleged because the Foundation faced obstacles, especially in the aspects of costs, and human resources, even conflicts between the Foundation and the teacher occurred. Conflicts faced are complicated, because they are not immediately resolved, resulting in less effective learning processes and leads to poor quality education.

In fact, the Foundation has a very strategic role to improve the quality of madrasas. Because the Foundation as the highest institution that regulates various policies related to madrasa management, ranging from recruitment of human resources, managerial, and financial to set madrasah achievement targets, as the Foundation Law No. 16 of 2001 says "the Foundation is a legal entity consisting of wealth that is separated and intended to achieve certain goals in the social, religious and humanitarian fields, which have no members. The function of the Foundation is as a non-profit organization to help the people's welfare. " The Foundation as an institution functions to provide protection, assistance, and services to the community in the social, religious and humanitarian fields. This means that the Foundation has a very important role in the organization of madrasas.

The role of the Foundation is not only to protect and serve the administration of madrasah, but also to improve the quality of madrasas. However, the reality shows that the Foundation which has a small focus on the administration of new madrassas. As the results of research conducted by Sumarni at the Darul Irfan Foundation in Depok, that the role of the Foundation in the management of Madrasah 
education is quite good. The Foundation has guidelines for the administration of education in madrassas and provides managerial guidance to the Head and the finance department and helps in conflict resolution [1]. It is different from the results of other studies, which show that there are still many obstacles faced by the management of Education foundations, starting with the legal entity establishment, to managing assets and costs. [2], as well as the results of research conducted by the Center for Research and Development indicate that the role of foundations in administering madrasas is not yet optimal, foundations, in general, are more focused on fostering management of facilities and costs, while on improving the quality of education implementation is still limited. [3]. Therefore, it is natural that the output of private madrasas is still low.

Indication of the low quality of private madrasah, because most of the foundations are not yet professional in managing madrassas. It must be admitted, so far, the Foundation in choosing management resources is more dominated by family relations, less attention to professionalism and competence. On the other hand government policies in empowering the Foundation have not been optimal, although the Foundation has an important position that determines the ups and downs of madrasas, but due to the limited competence of the Foundation plus coaching from the government in the form of regulations, quality improvement and technical guidance does not yet exist. Whereas in the National Medium Term Development Plan (RPJMN), it is indirectly stated that the government needs to collaborate with the private sector. In the National Medium-Term Development Plan (RPJMN), it is stated that strengthening cooperation between the government and the private sector, in this case, the Foundation (Foundation) by clearly regulating the government's contribution in helping schools.

In accordance with established criteria, the Baitul Muttaqin Foundation was targeted in this study, because the location is in the village, the conditions are simple and the community is still lacking attention to the importance of madrassas. The community prefers SMKs to madrasas. The foundation that manages the madrasa is an independent foundation, owned by the family, which of course faces many challenges in developing madrassas in a society where there is less interest in madrasas. Therefore, it is important to see how the role of the Foundation in the administration of madrasas, especially MA Daarul Istiqomah.

\section{Formulation of the problem}

The low index of madrasah development is suspected because the Foundation's contribution in administering madrasas is not optimal. Many foundations have established madrasas ranging from Rauthatul Athfal (RA) to Madrasah Aliyah, but in their management, they lack quality. This was allegedly because the management of the Foundation's management was less effective and frequent conflicts between the Foundation's management caused the programs to improve the quality of madrasas by the Foundation neglected. In addition, from the government there is also no policy that can be used as a standard by the Foundation as a reference in organizing madrasas. Another thing, the most important thing is the absence of guidance from the government towards the Foundation in carrying out its function as an madrasa organizer. So that the Foundation lacks understanding of its duties and functions in administering madrasas, which results in the variety of administering madrasas by the Foundation and results in low madrasah outputs.

\section{Research objectives and benefits}

This study aims to find out how the role of the Foundation in administering madrasah is seen from the managerial aspect, the aspect of improving the quality of madrasah and aspects of work networking. The results of this study can be used as input for the Directorate of Madrasah 
Education, Ministry of Religion, to formulate policies in order to improve the quality of madrasah through the Foundation.

\section{Conceptual framework}

\subsection{Evaluation}

The word evaluation is literally an assessment in a particular field regarding matters related to its activities. In term, evaluation is a process to determine the value of something [4]. Meanwhile according to James Popham "Evaluation is the process of finding, collecting and retrieving data (information) needed to give consideration to whether an ongoing program needs to be repaired, stopped or continued"[5].

Thus, the evaluation in this case is a process to gather information systematically, objectively, and structured to provide a decision on an object, [6] or a process of evaluating something based on established criteria or goals, which is then followed by decision making on the object being evaluated [7]. Program evaluation is carried out systematically, in detail, and using procedures that have been carefully tested with certain methods to obtain reliable data and evaluation can be used for policy makers.

The determination of policy will be appropriate if the data used as consideration is true, accurate, and complete, because evaluation can determine the achievement of a program. As revealed by Bigman "program evaluation, namely: (1) To find out whether the goals can be achieved, and how far can be achieved. (2) To find the principles that underlie the success of the program. (3) To carry out experiments with certain techniques in order to increase effectiveness. (4) To lay the foundation for conducting further research on the basis of the success of alternative techniques used. (5) To redefine the means to be used in achieving objectives, and even to redefine sub-objectives in accordance with research findings"[8].

What is meant by the Foundation in the context of this research is a collection of a number of people who are organized and from their activities as social institutions that are recognized and accepted for its existence, the Foundation as a legal entity, has the rights and fairness of the person or body that established the Foundation, as well as the Managers and other Foundation organs. . Whereas according to the Foundation Law No. 16 of 2004 the Jo No. 28 Foundation is a legal entity consisting of assets separated and intended to achieve certain objectives in the social, religious and humanitarian fields, which have no members.

The foundation referred to in this study is the Foundation as an organizer of both formal and non-formal education units. In this study, the Foundation is located as a) Legal entity in charge of madrasah; b) Owners of school capital and wealth; c) Stakeholders (vision) in organizing education and d) Responsible for organizing madrasah. (Law NO 28/2004 Amendment to Law No. 16 of 2001 concerning Foundations).

The implementation in question is management, referring to the understanding of the use of human resources or other resources that can be realized in planning, organizing, directing and controlling activities to achieve a certain goal [9].

Madrasah that are intended in this study are madarash described in Law on National Education System No. 20 of 2003, namely the type of secondary level formal education units that carry out the learning process which includes Madrasah Ibtidaiyah (MI), Madrasah Tsanawiyah (M.Ts) and Madrasah Aliyah (MA). The Madrasah is part of the national education system, which is demanded to improve its quality. 


\subsection{Education standard}

PP No.19 of 2005 explains that, National Education Standards (SNP) are the minimum criteria regarding the education system in the entire territory of the Republic of Indonesia. SNP aims to improve the quality of education in Indonesia and its function is as a basis in the planning, implementation and supervision of education in order to realize quality national education. The scope of the SNP includes eight components, namely Management Standards; Educator and Educational Staff Standards; Infrastructure Standards; Financing Standards; Process Standards; Content Standards; Grading Standards and Graduates Competency Standards. In connection with these standards, then in this study will be revealed how the role of the Foundation really is in meeting the eight standards, to improve the quality of madrasah.

\section{Research methodology}

This study uses qualitative methods with data collection techniques, namely interviews, observation, and study of documents. By using qualitative methods, researchers can see firsthand the actual situations and conditions in the field without any engineering that can improve the understanding of researchers of the phenomenon under study and are flexible so that it allows researchers to learn various interesting new fields [10].

To get more accurate data, data checking is done through triangulation techniques. In this case the information or data obtained through interviews with informants, tested with the results of observation and so on. In addition, triangulation of sources is also used, where certain information or data is obtained, asked again to informants who differ between informants and documentation, and triangulation of situations, where researchers pay close attention to how an informant tells, in his own circumstances and when together with others (11).

\section{Research results and discussion}

\subsection{Profile of the Baitul Muttaqiin foundation}

The number of foundations in Brebes Regency in 2017 was 23 foundations, one of which was the Baitul Muttaqiin Foundation. The foundation is an educational and social foundation, founded on July 17, 1995 located in the village of North Songgom, Songgom District, Brebes Regency, Central Java [12].

The foundation started because the Songgom community was troubled by the behavior of young people who often caused tantrums. The environment is very vulnerable, many young people have poor behavior, like to hang out and get drunk, because they don't have positive activities. They are not at school, because the Educational Institution is far away, while their parents are less able, so is the Madrasah Education Institute.

Madrasah educational institutions in the Songgom region are very limited. Although there are MTs and MAs, they are far away in Sitanggal, a distance of approximately $7-15 \mathrm{~km}$. So that many children who have difficulty getting an education such as the MA, are more concerned about the perception in the community that public schools in junior and senior high schools are easier to get jobs.

Through this Foundation Syuja'i can participate in nation building, especially in the field of religious and social education. Therefore, to achieve this goal the Foundation organizes formal and non- formal education. Formal education is Raudtatul Athfal (RA), Madrasah Ibtidaiyah (MI), Madrasah Tsanawiyah (MTs) and Madrasah Aliyah (MA). While non-formal educational institutions namely Al Qur'an Education Park (TPQ), Madrasah Diniyah and Manjelis Taklim. 


\subsection{Profile of Madrasah Aliyah Daarul Istiqomah}

Madrasah Aliyah (MA) Daarul Istiqomah was founded by the Baitul Muttaqiin Foundation in 1999. The Madrasa is located on Jalan Utara Songgom, Desa / Lor District, Brebes Regency, Central Java Province. Madrasah stand on Foundation land covering an area of 3,060 m2 with a building area of $500 \mathrm{~m} 2$ and a field area of approximately $81 \mathrm{~m} 2$. The madrasah building consists of four classrooms, one prayer room and one teacher's room equipped with warehouses and latrines [13]. The vision of the MA is the creation of the figure of warotsatul anbiya 'who has the knowledge of amaliyah and charity ilmiyah. To achieve this vision, the MA MISSION has been formulated, namely "Realizing the Muslim person who is fiddin and tadayyun", Realizing a Muslim person who is intellectually intelligent, emotional, and spiritual and Realizing the Muslim person who masters science and technology and is able to compete in the lives of global society). While the aim of establishing an MA is to form graduates who have insight into religious and general sciences and to form competent and noble personalities / national character and noble character and to form graduates who are able to apply worldly and ukhrowi disciplines.

The number of students since its establishment until 2017 recorded 399 students, class X there were 136 students, grade 11 there were 127 students and the rest were grade 12 [14]. The development of students every year is volatile. Since 2014 the number of students has continued to decline even to the lowest point in 2016, with only five students enrolling. The community prefers Vocational Schools to MA, with the reason that after graduating Vocational Schools can immediately get a job. In addition, because the infrastructure in MA is very limited, there are only teachers' rooms, warehouses, latrines and laptops, making them less attractive to prospective students. At first the Supreme Court was very popular among young people, and the number of students was quite large, because there were no MA in the area. Because of that the MA was the only educational unit in Songgom that was of interest to the children at the time. However, since the existence of the SMK development policy, followed by the rampant construction of SMK buildings including in the Songgom region also built 2 (two) SMKN. So since then, MA Daarul Istiqomah has suffered a setback, junior high school and MTs graduates have more vocational schools [15]. Since then, M.A students have decreased dramatically. Therefore, starting in 2016 the strategy was changed by freeing the cost of education [16].

With this strategy, in 2017 there will be an increase in the number of students. The Foundation makes publications in places of study such as majelis taklim, prayer rooms or in lectures. Schools and teachers make publications to schools such as junior high schools and MTs and to homes. For students who have not applied to other schools due to funding constraints, are targeted to be accommodated as prospective students of MA Daarul Istiqomah, and prospective students are given various school supplies such as shoes, bags and ATK to attract interest in entering the MA, although the results through this technique students increased, in 2017 there were 32 students [17]. In addition, the strategy was carried out to increase public interest, namely the Foundation opening boarding schools / boarding in 2017. This as a form of the Foundation wants the Supreme Court to improve and improve its quality. Another effort is to build an MTs building in the MA area, currently there are MTs managed by the Foundation but the building is far from the MA, so the graduate enters into another school.

\subsection{The role of foundations in improving the quality of Madrasah Aliyah (MA)}

Since the enactment of the 2003 National Education System Law number all schools are equal including madrassas. Then the madrasa is also required to have the same quality as public schools. Therefore, in order for the quality of madrasah to improve, madrasah organizing must also meet the 
National Education Standards (SNP) [18]. The SNP is a minimum criterion about the education system in the entire territory of the Republic of Indonesia, as an effort to improve the quality of education in Indonesia, especially private education managed by the Foundation. The eight standards are competency of graduates, educators and education personnel, management, processes, infrastructure, financing and assessment.

To meet the eight standards, the Foundation and the Head of Madrasah collaborate, so that the policy to fulfill the education standard is achieved. Given the challenges faced by the MA increasingly heavier, especially after the existence of school policies, where people prefer to enter SMK. To meet the SNP set by the government related to the implementation of madrassas. Especially the Supreme Court, the Foundation has made various efforts through cooperation both internal and external. Internally there have been various efforts with the headmaster and teachers including.

\subsubsection{Curriculum development}

Curriculum development is a major concern at MA Daarul Istiqomah as an effort to improve the quality of education, bearing in mind that the curriculum is the main reference in the administration of madrasah. Therefore, the Foundation proposes that the allocation of English language study time be increased from 2 hours of gramer material to 6 hours of study by increasing practice [19].

With this change in curriculum, madrasah student grades have slightly increased. From an average value of 6 to 7, from 5 to 6 . In addition to English language material, the curriculum is also added to the subject of Electrical (radio repair). This is done to rival SMK. Because young people in the Songgom region are mostly interested in SMK. However, this Electrical subject only lasted for one year, because the equipment was minimal due to the expensive cost, while the madrasah had no cost, finally the teacher was less active and Electrical skills lessons became common until now. These various methods are carried out with the intention that the MA output not only has good religious knowledge but is able to communicate through two languages namely Arabic and English and has special skills. Therefore, in the MA curriculum local content is added by including Arabic, English and Skills gramer. As a sense of responsibility to improve the quality of MA education, some Foundation administrators are also active in the learning process activities

Other curriculum development, such as learning methods or those related to academics, is given entirely to the Head of Madrasah through KKM and MGMP activities. The Foundation only supports madrasah activities. But the direction of education continues to be a concern of the Foundation, where the Foundation establishes a strategy to improve the quality of madrasah, so that community interest is increased, it is necessary to take steps to include language into superior madrasah.

The curriculum used at Madrasah Aliyah today is the 2013 curriculum as well as another madrasah. Allocation of time for the field of study of religious education Al Quran Hadith, Fiqh, Islamic History, and Aqeedah Morals) 8 hours of study, To strengthen religious material plus local content namely Arabic, Tajweedz, Nahu Shorof and Grammers and to the NU.

Specifically, for class X there are Grammar, Tajwid and Nahu Shorof subjects that are managed by Syujai as Chair of the Foundation, as local content subjects. Where the amount of time allocated for grammar is 6 hours, tajwid 1 hour and nahu shorof 1 hour. The number of hours taught by Chairwoman of foundation is 8 hours. While Fahrozi as the Foundation secretary manages the subjects of jurisprudence, aqeedah morals and SKI. While Husband as the Treasurer of the Foundation teaches Arabic subjects with an allocation of 8 hours of study time. This means that the Foundation also participates in the process of learning activities as a form of responsibility towards the implementation and improvement of madrasah quality. 
In a d d it i o n to formal study hours as a predetermined curriculum, there are also additional study hours to deepen the subject matter that starts from 06.15-07.15. Fields of study that are given additional study are those that are included in the UN including English [20]. This means that the Foundation is also involved in the process of deepening the material.

\subsubsection{Educators and education personnel}

One of the critical success factors in organizing an education unit is the fulfillment of adequate aspects of educators and education personnel both in quality and quantity. In quality, fulfillment of competency standards and qualifications of madrasah educators and education staff. In terms of quantity, the fulfillment of the number of educators and education staff has reached a balance between the needs and the amount available to support teaching and learning activities.

Educators in madrasah, according to article 28 SNP are teachers who teach in madrasah. Whereas education staff includes principals / madrasah, supervisors, administrative staff, library staff, laboratory staff, cleaning staff and security staff.

The number of educators in MA Daarul Istiqomah is 13 people, with S.1 education background and 45 students (three groups), [21]. This means that the quantity of educators has been fulfilled, even more so, because the ratio of the ratio of teachers to students is 1 to 4 students. Meanwhile in the national education standards. The ratio of teacher to student ratio is one to 38 students. This means that if it is measured based on a standardized process calculation that has been regulated the number of teachers in the Supreme Court is far more ideal, the conditions should be far more qualified. However, due to inadequate infrastructure and financing and ineffective learning, the quality of madrasah is still low. While aspects of the qualifications of teachers are all educated S1 and teach the field of study in accordance with their educational background or not mismatch. This means that in terms of teacher education qualifications in accordance with Law No. 14 of 2005 concerning Teachers and Lecturers which requires teacher education to have a minimum of S1 education.

The teacher qualifications meet the standards. In addition, four teachers have received certification. The effectiveness of learning in madrasah should be quite effective. However, it turns out that certification does not have an optimal effect on improving MA quality. Especially since 2016 the certification allowance has been delayed. Because it is considered the lesson hours that are taught by the teacher are less fulfilled.

To be eligible for teacher certification to continue, teachers must meet the allocation of time for class hours, which is 24 hours. Therefore, in order for these requirements to be met, the madrasah gives additional tasks to teachers including becoming Deputy Chief of the MA, teaching local content and other assignments.

The foundation actually wants to have competent teachers as described by Dede Rosyada, namely teachers have professional abilities, adequate teaching skills, have good personal intelligence and have good social intelligence "[22], but what the desire has not been accomplished, because the ability of the Foundation is still limited.

Therefore, the teaching staff in the Supreme Court has only fulfilled the qualification aspect, while the competency aspect has not been fulfilled, because the teacher has never received training from a professional institution. Likewise, the teaching staff is inadequate in terms of both qualifications and quantity, because the administrative staff are only one person. While other workers are not yet available.

The Foundation in terms of improving the quality of teaching staff has tried but is limited to providing motivation such as providing opportunities and encouraging teachers to continue further studies and participating in socialization activities at the Ministry of Religion Education and Training Center, but this activity is still very limited. Teachers are limited to participating in MGMP activities. 
Likewise the Head of Madrasah to discuss various matters related to madrasah development only through the Madrasah Working Group (KKM), not following training in professional institutions. Regarding the recruitment of educators, it has been quite wise, because it has been arranged in the Bylaws of the Foundation, which is the technically the Head of the madrasah and the highest decision is the Foundation. If the nominating head of the madrasah comes from the board of trustees, then the person concerned must resign from the management of the Foundation. This is in accordance with the AD/ART of the Foundation, namely the appointment of Madrasah Staff and employees is carried out through a recruitment procedure by the Madrasah Head by requesting approval from the Foundation.

This Foundation Policy has been implemented. Likewise, it is also related to the dismissal of Madrasah Heads, Teachers, Staff and Employees who have been terminated because they have been dismissed by a management meeting because they have taken actions that are contrary to the Foundation's Statutes and Rules of Association. This dismissal is carried out through a gradual procedure that is through a family verbal warning, a maximum of two (2) times, a written warning one (1) time and a written warning one (1) time, the last is the revocation of the mandate of the concerned and the end of the tenure due to completion term of office or due to death [23].

\subsubsection{Madrasah management}

As a consequence of curriculum development in Madrasah, the Foundation not only aims at developing curriculum but also is responsible for various other activities. From the interview results, it shows that there is a role for the Baitul Muttaqin Foundation. The Foundation Board and the headmaster of madrasah work closely with the Head of Madrasah on the management of the madrasah. This form of cooperation is carried out through meetings that are held at least twice a year, namely the beginning of the year and the end of the year sometimes also in the middle of the year or as needed. If there are problems that need to be resolved, then the meeting can be held several times. The agenda of the meeting usually discussed various matters relating to the budget of the new school year, admission of new students, acceptance and expenditure of funds and other issues that were considered urgent. At the beginning of the year the Foundation together with the Head of Madrasah prepared the planning for admission of new students and prepared the Madrasah Expenditures Budget Plan (RABM) and identified the need for infrastructure that needed to be repaired and needed to be completed, making new Decrees (SK) for educators and education staff and others related to smooth learning process.

Likewise, in the managerial management of the Supreme Court, both administrative and financial management. According to Syaefullah, the Foundation is not scheduled to formally coordinate coaching, but the realization is real, in every madrasah activity it is always discussed with the Foundation and at the beginning of the year, between Foundation administrators conduct joint preparatory meetings with the head of the MA both for determining the operational budget of the madrasah and accepting new students as well as other activities through meetings that were attended by Foundation administrators and teachers. Admission of new students is done jointly between madrassas and foundations. Madrasah conduct door-to-door visits to residents' homes, socialization to SMP and MTs. While the Foundation conducts outreach to mosques, mosques and other public places through recitation and public lectures.

\subsubsection{Learning process}

Foundations have a high responsibility in administering madrasah, therefore as a form of responsibility to improve the quality of MAs, the Foundation also plays a role not only in determining the direction of education but actively in managing MA education institutions. This is

done by being involved in the learning process. Chairpersons, secretaries and treasurers of the 
Foundation take part as teachers who teach certain subjects [24]. The Chairperson of the Foundation (Syuja'i) teaches English with a method of focusing more on practice (conversation) This is done so that English subject matter is more attractive to students. This effort is reaping the results, with increasing student ability, it is evident from the student test scores increased from 5 to 6 and from 6 to 7. Practice English is used as a superior lesson in madrasah. One effort to push in that direction is to open boarding or boarding schools.

\subsubsection{Fulfillment of infrastructure}

Infrastructure is the most important thing in the implementation of education, without the means of pre-education facilities will not run effectively. For this reason, the fulfillment of infrastructure must be a particular concern. At MA Daarul Istiqomah the fulfillment of infrastructure is the responsibility of the Foundation. This program is the first and foremost. Since the establishment of the madrasah, the Foundation has provided various needs for the implementation of the madrasah, from the provision of land, buildings to the needs of the madrasah [25]. The Foundation, at the beginning of each new school year and the end of the year, always has a meeting. To discuss various issues related to infrastructure. At the beginning of the year, the Foundation always tried to fulfill the facilities through family and friends. Meanwhile, at the end of the year, the Foundation conducts a meeting to analyze madrasah needs, both the facilities that need to be repaired and those that do not yet need to be completed, and calculates the costs involved.

\subsubsection{Financing}

Madrasah operational funding sources only depend on BOS, because students are free of charge. The exact amount of BOS is Rp 1,400,000 (one million four hundred thousand rupiah) year, with 45 students. While the number of teachers and administration are 14 people and the number of hours that must be paid is 51 hours of study. While the hourly honorarium is Rp. 20,000, the Deputy Head allowance is Rp. 50,000 and the Madrasah Head is Rp. 100,000. This means that the costs that must be available are for the purposes of teacher honorarium, Principal and Wakit plus TU [26]. These funds are very minimal, insufficient, but what power because the madrasah has to live, then all those involved in the Madrasah receive a meager salary. With such a humble honor, the teacher must look for extras outside such as teaching elsewhere, trading and others. This condition causes the teacher to be busy, often late or absent. So that the impact on the learning process is less effective. The Foundation and the Head of Madrasah do not dare to act firmly (ewuh pakewuh) to the rules and discipline of the teacher. Because the Foundation feels that it has not been able to give its rights properly. So that the condition is left without warning.

\subsection{The role of the foundation in the expansion of networking}

To develop the quality of madrasah requires knowledge and insight, so that madrasah management is more innovative. Therefore, the Foundation has collaborated with the As Syafi'iyah Foundation, but this collaboration is only limited to non-formal. But at least get a lot of information related to the administration of madrassas. As there is input on HR management, where in 2017 the Foundation board can compile AD/ART on HR management. In the AD/ART set about the appointment of teachers. Criteria and Requirements for Appointment of Madrasah Principals and teachers for Daarul Istiqomah Madrasah are defined as Bachelor of Islamic Colleges or Public Colleges, both public and private. The principal's profile is to be able to read the Koran fluently, physically and mentally 
healthy, have a morality, be able to teach well, have loyalty to the Foundation and have knowledge about education.

In the $\mathrm{AD} / \mathrm{ART}$ it is also explained that the term of office of the Head of Madrasah is set to a maximum of 4 years and can then be re-elected for a period through a predetermined procedure namely election. While related to the dismissal of the Madrasah Head, it was carried out through a meeting of the members of the Management.

The regulation has been implemented starting in 2014. However, the teacher's response has not yet been established. Therefore, the Foundation adopted a policy of appointing old people who were willing. According to Syuja'i, this is because seen from the ability of madrasah who have not been able to provide job allowances properly, while the responsibilities are heavy. So the teachers are not interested in being the head.

\subsection{The role of the foundation in overcoming conflict}

Conflict is something that cannot be avoided in human life, even as long as human life will always be confronted and wrestle with conflict, as well as organizational life. In this case, the Foundation, as an organization that is always faced with changes or new innovations, is very vulnerable to cause conflict (destructive), especially if it is not accompanied by adequate understanding of developing ideas.

One source of conflict is when there is a change or innovation, as happened in the Daarul Istiqomah Madrasah related to policy changes regarding the appointment and dismissal of the Madrasah Head's position. The new rule applied is the appointment of a Madrasah Head of at least two (2) candidates who are submitted to the madrasah and are democratically elected in an open meeting then endorsed by the Chairperson of the Foundation [27].

The policy began to be implemented, because two periods (19) served as the Head of MTs. He was replaced by the new Head who was previously a teacher. Then the former Head was appointed as Deputy Head of the MTs Curriculum Division, also as a teacher at MA Daarul Istiqomah. But there was a conflict between the Foundation and the former Head of Madrasah. The former head in performing his duties lacked discipline, with the reason that the teacher's salary was small so he was busy outside, often with permission and late to enter. While the new Madrasah Head who was appointed in 2014 did not dare to reprimand, because the teacher had previously been his boss, finally until now the teacher was teaching arbitrarily. According to Syuja'i, the conflict between the Foundation and the teacher was due to suddenly new rules being applied, while the Foundation did not conduct prior socialization, so the teacher felt offended. This conflict is prolonged because it is not quickly resolved and the Chairman of the Foundation is not firm. As a result, the teacher's behavior is less friendly, less disciplined and less responsible, both in carrying out the tasks and their attendance.

This conflict is actually still at a mild level. Because the teacher concerned still wants to teach in the MA. But the Foundation could not overcome it, so it dragged on until now. The foundation is less assertive in making policies, there is a feeling in Javanese "ewuh pakewuh" because the teacher is more senior. Therefore, the Foundation and the Head of the Supreme Court can only convey their appeals to the teacher during the meeting and the flag apple every Monday, so that the teachers can teach according to a predetermined schedule. But there has been no change to date and finally there was a status quo. 


\section{Closing}

\subsection{Conclusion}

Based on the explanation above, it can be concluded that the implementation of madrasah by the Foundation has been running, but it is less than optimal, especially in managerial roles, network expansion and conflict resolution. From the managerial side, it can be seen that the supervision and monitoring and guidance of madrasah management is still limited, only at the level of appeal. The Foundation felt that they had been directly involved in the learning process and every meeting held by the madrasah was always present. So, it is deemed necessary to have no control or monitoring or guidance for madrasah management. Network expansion can be done both internally and externally. Internally, collaboration with madrasah with the Madrasah Head, teachers and administration is quite adequate. Externally, the collaboration was carried out with a professional friend, namely the board of the Asy Syafiiyah Songgom Foundation. Even though the collaboration is only limited to brainstorming or discussion, the results are quite influential to the changes in the Foundation's program related to HR management innovation. Another thing that paid enough attention was that the conflict between the teacher and the Foundation had not been resolved. Because conflict management has not been optimal, conflicts without serious handling either through deliberation or through other roads so that it drags on. The Foundation did not dare to take a stand, arguing because the salaries given to teachers were inadequate and the teacher who was considered to have the conflict was more senior. So, there is a status quo. The role of the Foundation in meeting the eight National Education standards has been running but is still limited. The Foundation is more dominant in the aspect of fulfilling infrastructure, while in other aspects it is still limited. Likewise, the MA management aspect has not yet proceeded. Madrasah management is given in full to the Madrasah Head without monitoring and evaluation. The Foundation itself does not have a clear program on a regular basis, so it cannot be measured to what extent the madrasah program targets can be achieved.

\subsection{Recommendation}

From these conclusions there are a number of notes that need to be recommended that:

1 The Ministry of Religion should make policies that can be used as a reference by the Foundation to carry out its role in the administration of madrasah. So that the role and responsibilities of the Foundation in organizing madrasah are more effective.

2 The Ministry of Religion needs to make policies to improve the quality of teaching staff by increasing the percentage of training for private teachers. So that educators in the private madrasah run by the Foundation have the opportunity to add insight.

3 Foundations need to provide guidance to both academic and managerial madrasah for educational staff. So that madrasah management is more effective in improving the quality of adrasah.

4 Foundations need to strengthen cooperation with internal madrasah and expand networking with external parties so that they gain insights into improving the quality of madrasah.

5 The Foundation needs to hold intensive deliberations to find solutions for conflict management, so that the conflicts that occur can be managed well, not protracted, so that harmony is created between the Foundation with the teacher or madrasah. 


\section{Refrences}

[1] Peran Yayasan Dalam Pengelolaan Pendidikan Madrasah", Edukasi, Jurnal Penelitian Pendidikan Agama Dan Keagamaan, Kementerian Agama, Vol 16 (2), 2018

[2] Risma Sari, et al, "Kesadaran Badan Hukum Yayasan Pendidikan di Indonesia (Persepsi dan Kesadaran Hukum Masyarakat)", De Jur, Jurnal Penelitian Hukum, Volume 16, (3), September 2016.

[3] Imran Siregar, et al, "Peran Yayasan Dalam Penyelenggaraan Pendidikan Madrasah", Laporan Hasil Penelitian, Puslitbang Pendidikan Agama dan Keagamaan Balitbang dan Diklat Kementerian Agama, 2017

[4] Suiono Anas, “ Pengantar Evaluasi Pendidikan”, Jakarta: PT. RajaGrafindo Persada, 2005:1

[ 5] W. James Popham, "Modern Educational Evaluation", New Jersey: Prenctice Hall Inc. 1981:7

[6] Norman E. Grounlund and Robert L. Linn, "Measurment and Evaluation in Teaching", New York: Mac Milan Publishing Company, 1990: 5

[7] Djaali, Pudji Mulyono, dan Ramly, "Pengukuran Dalam Bidang Pendidikan", Jakarta: PPs. UNJ, 2004:1

[8] Leonard Rutman, "Evaluation Research Methodology “, New Delhi: Sege Publication India PVT. Ltd, 2 ed., 1984:123.

[9] George R. Terry, “Prinsip-Prinsip Manajemen”,Bumi Aksara cet. 11, 2013

[10] Morissan, "Metode Penelitian Survei”, Jakarta: Kencana Prenada Media Group, 2012: 22

[11] Hamidi, "Metode Penelitian Kualitatif", Malang: Universitas Muhammadiyah, 2004;83

[12] Documents Yayasan Baitul Muttaqqin, Brebes: 1995.

[13] Profile of Madrasah Aliyah Daarul Istiqomah,Brebes: 2015.

[14] Dokumen Data of MA Daarul Istiqomah,Brebes: 2017.

[15] Interview with Fahrozi, Pengurus Yayasan Baitul Muttaqin Brebes, July, 17: 2017.

[16] Interview with Suja'i, Ketua Yayasan Baitul Muttaqin, Brebes, July,18: 2017.

[17] Interview with Fahrozi, Pengurus Yayasan Baitul Muttaqin Brebes, July, 17: 2017

[18] Peratuaran Menteri Pendidikan dan Kebudayaan (Permendiknas NO 19: 2005).

[19] Interview with Suja'i, Ketua Yayasan Baitul Muttaqin, Brebes, July 17: 2017.

[20] Interview with Sumiyati, Bendahara Yayasan Baitul Muttaqin, Brebes, May 17: 2017

[21] Profile Madrasah Aliyah (MA) Daarul Istiqomah, Brebes: 2017

[22] Dede Rosyada, “Madrasah dan Profesionalisme Guru”, Depok, Kencana 2013: 29

[23] Documents Yayasan Baitul Muttaqqin, Brebes : 2014

[24] Interview with Fahrozi, Bendahara Yayasan Baitul Muttaqin, Brebes, July 17: 2017

[25] Interview with Syaefullah Kepala MA Daarul Istiqomah Brebes, July 17: 2017

[26] Interview with Nining, Bendahara MA Darul Istiqomah, Brebes, July $18: 2017$

[27] Dokumen Data Yayasan Baitul Muttaqin, Brebes: 2014 